\title{
Nitric oxide activates intradomain disulfide bond formation in the kinase loop of Akt1/PKB $\alpha$ after burn injury
}

\author{
X.-M. LU ${ }^{1-3}$, R.G. TOMPKINS ${ }^{1-3}$ and A.J. FISCHMAN ${ }^{2,3}$ \\ ${ }^{1}$ Surgical Service, Massachusetts General Hospital; ${ }^{2}$ Harvard Medical School; \\ and ${ }^{3}$ Shriners Hospital for Children, Boston, MA, USA
}

Received November 12, 2012; Accepted December 14, 2012

DOI: 10.3892/ijmm.2013.1241

\begin{abstract}
Severe burn injury is an acute inflammatory state with massive alterations in gene expression and levels of growth factors, cytokines and free radicals. During the catabolic processes, changes in insulin sensitivity and skeletal muscle wasting (unintended loss of 5-15\% of lean body mass) are observed clinically. Here, we reveal a novel molecular mechanism of $\mathrm{Akt1} /$ protein kinase $\mathrm{B} \alpha(\mathrm{Akt} 1 / \mathrm{PKB} \alpha)$ regulated via cross-talking between dephosphorylation of $\mathrm{Thr}^{308}$ and S-nitrosylation of $\mathrm{Cys}^{296}$ post severe burn injury, which were characterized using nano-LC interfaced with tandem quadrupole time-of-fight mass spectrometry (Q-TOF) ${ }^{\text {micro }}$ tandem mass spectrometry in both in vitro and in vivo studies. For the in vitro studies, Akt1/PKB $\alpha$ was S-nitrosylated with S-nitrosoglutathione and derivatized by three methods. The derivatives were isolated by SDS-PAGE, trypsinized and analyzed by the tandem MS. For the in vivo studies, Akt1/PKB $\alpha$ in muscle lysates from burned rats was immunoprecipitated, derivatized with HPDP-Biotin and analyzed as above. The studies demonstrated that the NO free radical reacts with the free thiol of $\mathrm{Cys}^{296}$ to produce a Cys ${ }^{296}$-SNO intermediate which accelerates interaction with $\mathrm{Cys}^{310}$ to form $\mathrm{Cys}^{296}-\mathrm{Cys}^{310}$ in the kinase loop. MS/MS sequence analysis indicated that the dipeptide, linked via $\mathrm{Cys}^{296}-\mathrm{Cys}^{310}$, underwent dephosphorylation at $\mathrm{Thr}^{308}$. These effects were not observed in lysates from sham animals. As a result of this dual effect of burn injury, the loose conformation that is slightly stabilized by the Lys ${ }^{297}-\mathrm{Thr}^{308}$ salt bridge may be replaced by a more rigid structure which may block substrate access. Together with the findings of our previous report concerning
\end{abstract}

Correspondence to: Professor Alan J. Fischman, Shriners Hospital for Children, 51 Blossom Street, Boston, MA 02114, USA

E-mail: aajjff@gmail.com

Abbreviations: Akt1/PKB $\alpha, \mathrm{Akt} 1 /$ protein kinase $\mathrm{B} \alpha$; CAM, carboxyamidomethyl cysteine; CMC, carboxymethyl cysteine; GSNO, S-nitrosoglutathione; PH, pleckstrin homology; PTM, posttranslational modification; Q-TOF, tandem quadrupole time-of-fight mass spectrometry; TBSA, total body surface area

Key words: Akt1/protein kinase B $\alpha$, S-nitrosylation, disulfide bond, $\mathrm{MS} / \mathrm{MS}$ mild IRS-1 integrity changes post burn, it is reasonable to conclude that the impaired $\mathrm{Akt1} / \mathrm{PKB} \alpha$ has a major impact on FOXO3 subcellular distribution and activities.

\section{Introduction}

Metabolic alterations that are produced by critical illness such as burn trauma are associated with a hypermetabolic/inflammatory state, increased protein catabolism (with resulting muscle wasting) and insulin resistance. Muscle wasting can lead to muscle weakness that can result in hypoventilation, prolongation of dependence on mechanical ventilation, prolonged rehabilitation and even death (1-4). Insulin resistance is a well established state in critically ill patients and is considered to play a key role in the metabolic derangements and muscle wasting. Binding of insulin to its receptor (IR) activates IR tyrosine kinase, which then phosphorylates IR substrates (IRSs). Phosphorylation of IRS1 and IRS2 transduces the signal from IR to phosphatidylinositol-3-kinase (PI3-kinase) (4,5). Post-translational modifications (PTMs) of the insulin signaling system are considered to be major disease-dependent events that regulate glucose transport via GLUT-4 translocation and protein synthesis (6-12).

$\mathrm{Akt} 1 / \mathrm{PKB} \alpha$ is a critical downstream mediator of the IR/IRS/PI3-kinase pathway of the insulin signaling system (13-17). Akt1/PKB $\alpha$ consists of three structural features: the N-terminal pleckstrin homology $(\mathrm{PH})$ domain, a large central kinase domain and a short $\mathrm{C}$-terminal hydrophobic motif. High specific binding of the $\mathrm{PH}$ domain with membrane lipid products of PI3-kinase recruits Akt1/PKB $\alpha$ to the plasma membrane where phosphorylations of $\mathrm{Thr}^{308}$ (pThr ${ }^{308}$, kinase domain) and $\operatorname{Ser}^{473}\left(\mathrm{pSer}^{473}\right.$, hydrophobic motif) occur. Phosphorylation of $\mathrm{Thr}^{308}$ partially stimulates kinase activity; however, additional phosphorylation of $\mathrm{Ser}^{473}$ is required for full activity. Activation is associated with a disordered to ordered transition of a specific $\alpha \mathrm{C}$ helix of $\mathrm{Akt} 1 / \mathrm{PKB} \alpha$ via an allosteric mechanism. A salt bridge between the side-chain of Lys $^{297}$ and the phosphate group of $\mathrm{pThr}^{308}$ in this $\alpha \mathrm{C}$ helix contributes to an ordered activation segment from ${ }^{292} \mathrm{DFG}$ to $\mathrm{APE}^{319}$ (18-21). Reversible dephosphorylations of $\mathrm{Thr}^{308}$ and $\mathrm{Ser}^{473}$ by protein phosphatase 2A (PP2A) and PH domain leucine-rich repeat protein phosphatase (PHLPP $\alpha$ ) also occur in the Akt1/PKB $\alpha$ activation/deactivation cycle (22-25). 
In addition to the role of reversible phosphorylation/dephosphorylation in the regulation of $\mathrm{Akt} 1 / \mathrm{PKB} \alpha$ activity, this kinase is also reversibly inactivated by $\mathrm{S}$-nitrosylation under conditions that result in persistently increased production of nitric oxide; such as after burn injury (13,26-29). Thiol titration and NMR data indicate that a disulfide bond $\left(\mathrm{Cys}^{60}-\mathrm{Cys}^{77}\right)$ exists in the kinase PH domain (30). A second disulfide bond in the critical kinase activation loop $\left(\mathrm{Cys}^{297}-\mathrm{Cys}^{311}\right)$ has been reported to be associated with dephosphorylation under oxidative stress in vitro (31). In addition, it has been shown that when $\mathrm{Cys}^{224}$ of Akt1/PKB $\alpha$ is mutated to a Ser residue, the kinase becomes resistant to $\mathrm{NO}$ donor-induced S-nitrosylation and inactivation; suggesting that this residue is a major $\mathrm{S}$-nitrosylation acceptor site (28). In vivo S-nitrosylations of the insulin receptor $\beta$ and $\mathrm{Akt} 1 / \mathrm{PKB} \alpha$ result in reductions in their kinase activities (27). These data suggest that the redox status of $\mathrm{Akt1} / \mathrm{PKB} \alpha$, regulated by $\mathrm{NO}$, is a second factor in the PTM that modulates kinase activity (via dynamic conformational changes) and thus GLUT-4 trafficking and protein synthesis. Nevertheless, to date, published data on the reversible phosphorylation(s) and S-nitrosylation(s) relevant to $\mathrm{Akt} 1 / \mathrm{PKB} \alpha$ activation, conformation and regulation have not provided conclusive information concerning their interrelationships nor critical S-nitrosylation sites involved in the kinase activation/deactivation cycle.

Recent technical developments have made it feasible to study the molecular details of these important processes. These techniques include: i) sensitive and site-specific procedures for the detection of S-nitrosylation based upon nano-LC interfaced with tandem MS $(32,33)$; ii) the Biotin-Switch method for qualitative discrimination of the thiol state between free, disulfide bonded and S-nitroylated cysteine residues under carefully defined conditions (34-39). Potential problems related to quantification with this technique have been discussed previously (33); and iii) highly specific anti-Akt1/ $\mathrm{PKB} \alpha \mathrm{mAbs}$ that can be used to immunoprecipitate quantities of protein that are sufficient to yield SDS-PAGE bands with Coomassie brilliant blue R-250 staining which are compatible with tandem MS analysis.

Burn injury-associated impairments in IRS1 signaling and attenuated IR-IRS-PI3K-Akt/PKB activation have been the major focuses of our research team $(9,26,29,33)$. Significantly reduced phosphorylations of $\mathrm{Ser}^{473}$ and $\mathrm{Thr}^{308}$, as well as decreased Akt/PKB kinase activity were observed after burn injury [55\% total body surface area (TBSA), day 3] and insulin stimulation (26). However, the interrelationship between impaired kinase activity and the loop disulfide bond (31) reported under oxidative stress remains unclear. In the present study we investigated the interaction between S-nitrosylation and phosphorylation at $\mathrm{Cys}^{296}-\mathrm{Lys}^{297}$ and $\mathrm{Thr}^{308}-\mathrm{Phe}^{309}-\mathrm{Cys}^{310}$ in the kinase loop at the proteomic level.

Specifically, the following issues need to be studied: i) the ability of $\mathrm{Cys}^{296}$ to chemically quench elevated levels of free radicals, mainly nitric oxide; ii) loop conformational changes associated with two types of PTMs; iii) quantitative proteomics of $\mathrm{Akt} 1 / \mathrm{PKB} \alpha$ by stable isotope labeling in mice. In this study, we obtained MS/MS sequence data to characterize the thiol states of $\mathrm{Cys}^{296}$ in the kinase activity loop of Akt1/PKB. These measurements were possible despite the extremely low level of nitrosylated protein (at the $10^{-15} \mathrm{pmol}$ level, the chance of posi- tive hits is $\sim 25 \%$ with lysates prepared from $25 \mathrm{mg}$ of soleus muscle). The biochemical role of S-nitrosylation at Cys ${ }^{296}$ was characterized as an intermediate state which reduces the kinetic barrier to form the disulfide bond with Cys ${ }^{310}$ within the activity loop. This occurs simultaneously with dephosphorylation of $\mathrm{pThr}^{308}$ after burn injury. The facts that no other disulfide bonds associated with $\mathrm{Cys}^{296}$ were detected suggest that they may be thermodynamically forbidden; due to geometry and/or dihedral strain. The data obtained with soleus muscle from burned and sham-treated rats indicates that NO-mediated formation of the $\mathrm{Cys}^{296}-\mathrm{Cys}^{310}$ disulfide bond (which likely downregulates kinase activity) plays a reciprocal role with formation of a $\mathrm{Lys}^{297}-\mathrm{pThr}^{308}$ salt bridge (which upregulates kinase activity) during disease-associated reversible activation/deactivation processes.

\section{Materials and methods}

Chemicals. Acetonitrile (ACN, LC-MS Chromasolv), formic acid (FA), glacial acetic acid, LC-MS grade water, dithiothreitol (DTT), iodoacetic acid, iodoacetamide, [Glu] fibrinopeptide B, methyl methanethiolsulfonate (MMTS), S-nitrosoglutathione (GSNO), sodium L-ascorbate, neocuproine, N,N-dimethylformamide (DMF), dimethyl sulfoxide (DMSO) were obtained from Sigma Chemical Co. (St. Louis, MO). SDS-PAGE Ready gels (4-15\% Tris-HCl, cat. no. 161-1122), Laemmli sample buffer (cat. no. 161-0737) and Coomassie brilliant blue R-250 (no. 161-0436) were obtained from Bio-Rad. Trypsin profile IGD kits (cat. no. PP0100) were obtained from Sigma. Anti-Akt1/PKB $\alpha$ monoclonal antibody (cat. no. 05-798; lot, 26860) and inactive Akt1/PKB $\alpha$ (cat. no. 14-279) were purchased from Upstate (Charlottesville, VA, USA). Streptavidin agarose CL-4B (cat. no. 85881) was a product of Fluka (Milwakee, WI, USA). HPDP-Biotin (cat. no. 21341) and Iodoacetyl-LC-Biotin (cat. no. 21333) were purchased from Pierce (Rockford, IL, USA).

Mapping of cysteine residues in inactive Akt1/PKB $\alpha$. Inactive $\mathrm{Akt} 1 / \mathrm{PKB} \alpha(10 \mu \mathrm{g}, 0.18 \mathrm{nmol}$, in $10 \mu \mathrm{l}$ stock solution) was transferred to a siliconized Eppendorf tube $(0.6 \mathrm{ml})$ containing Laemmli sample buffer (2X, $10 \mu 1, \mathrm{pH}$ was adjusted to 8.0) and DDT (2 $\mu 1,20 \mathrm{nmol}, \mathrm{PBS}, \mathrm{pH} 8.0)$, and the solution was kept at $95^{\circ} \mathrm{C}$ for $5 \mathrm{~min}$. Freshly prepared Iodoacetyl-LC-Biotin $(15 \mu \mathrm{l}$, $55 \mathrm{nmol}$, in DMF) was added to the denatured protein solution followed by stirring for an additional $15 \mathrm{~min}$ at room temperature. The resulting biotinylated $\mathrm{Akt} 1 / \mathrm{PKB} \alpha$ was purified by SDS-PAGE and stained with Coomassie brilliant blue R-250. The protein bands were excised $(\sim 1 \mathrm{~mm}$ size $)$ and digested (Akt1/PKB $\alpha$ : trypsin 25 , overnight at $37^{\circ} \mathrm{C}$ ) with a Trypsin Profile IGD kit according to the manufacturer's instructions. The biotinylated peptide mixture was captured by gentle stirring with streptavidin agarose CL-4B (30 $\mu$ l packed) at room temperature for $1 \mathrm{~h}$ (final vol, $100 \mu \mathrm{l})$. The streptavidin beads were washed with PBS $(0.5 \mathrm{ml} \mathrm{x3})$, followed by water/ acetonitrile (ACN 10\%, $0.5 \mathrm{ml}$ x3). Biotinylated peptides were released from the streptavidin beads with formic acid $(70 \%$, $100 \mu \mathrm{l}$ ) at room temperature for $15 \mathrm{~min}$ with brief vortexing. The supernatant containing biotinylated peptides was transferred to a new vial and the formic acid was evaporated with a SpeedVac. The biotinylated peptide mixture was resuspended 
in water/acetonitrile (ACN, $2 \%$, with $0.1 \% \mathrm{FA}, 70 \mu \mathrm{l})$, and the aliquots $(10 \mu \mathrm{l})$ were injected into a Waters CapLC-tandem quadrupole time-of-fight mass spectrometry (Q-TOF) system.

Identification of disulfide bonds in inactive Akt1/PKB $\alpha$. Inactive Akt1/PKB $\alpha(10 \mu \mathrm{g}, 0.18 \mathrm{nmol}$, in $10 \mu \mathrm{l}$ stock solution) was transferred into a siliconized Eppendorf tube $(0.6 \mathrm{ml})$ containing Laemmli sample buffer $(2 \mathrm{X}, 10 \mu \mathrm{l}$, $\mathrm{pH} 8.0)$ and iodoacetamide ( $2 \mu 1,20 \mathrm{nmol}, \mathrm{PBS}, \mathrm{pH}$ 8.0). The mixture was maintained at $95^{\circ} \mathrm{C}$ for $5 \mathrm{~min}$ and then stirred at room temperature for an additional $15 \mathrm{~min}$. The Akt1/PKB $\alpha$ was purified by SDS-PAGE and stained with Coomassie brilliant blue R-250. The protein bands were processed as above.

Identification of $N O$ acceptor sites in inactive Akt1/PKB $\alpha$. Three samples of inactive Akt1/PKB $\alpha(10 \mu \mathrm{g}, 0.18 \mathrm{nmol}$, in $10 \mu \mathrm{l}$ stock solution) were treated with GSNO ( $250 \mathrm{nmol}, 50 \mu \mathrm{l}$ PBS, pH 8.0, 200-fold excess/thiol group) for $1 \mathrm{~h}$ at room temperature in the dark in siliconized Eppendorf tubes $(0.6 \mathrm{ml})$. Separation of Akt1/PKB $\alpha$ and GSNO was achieved by two successive acetone/water precipitations $(0.3 \mathrm{ml}, 70 \% \mathrm{ACN})$ at $-40^{\circ} \mathrm{C}$ for $10 \mathrm{~min}$. The supernatants (containing GSNO) were removed by centrifugation at $14,000 \mathrm{x}$ g for $2 \mathrm{~min}$. The kinase pellets were resuspended in blocking buffer $(100 \mu 1,20 \mathrm{mM}$ Tris-HCl, pH 7.7, 2.5\% SDS, $20 \mathrm{mM}$ MMTS, 1 mM EDTA, $0.1 \mathrm{mM}$ neocuproine) at room temperature for $1 \mathrm{~h}$ with gentle stirring (1 mm ID x5 mm bar). Excess MMTS was removed by acetone $(100 \%, 0.3 \mathrm{ml})$ precipitation (as above), and the protein pellets were resuspended in PBS (50 $\mu 1, \mathrm{pH} 8.0)$. Freshly prepared iodoacetic acid $(5 \mu 1,2 \mathrm{mM}$ in PBS, $\mathrm{pH}$ 8.0), HPDP-Biotin (5 $\mu 1,2 \mathrm{mM}$ in DMSO), Iodoacetyl-LC-Biotin $(5 \mu \mathrm{l}, 2 \mathrm{mM}$ in DMF) and sodium ascorbate $(20 \mu 1,5 \mathrm{mM}$, PBS) were added to the three vials containing nitrosylated $\mathrm{Akt} 1 / \mathrm{PKB} \alpha$, respectively. The reaction mixtures were stirred at room temperature for $15 \mathrm{~min}$ (iodoacetic acid and IodoacetylLC-Biotin) or $1 \mathrm{~h}$ for the thiol-disulfide exchange reaction. Aliquots of SDS sample buffer (2X, with 5\% 2-mercaptoethanol, $50 \mu \mathrm{l}$ ) were added to the protein solutions, and the mixtures were incubated at $95^{\circ} \mathrm{C}$ for $5 \mathrm{~min}$. The derivatized proteins were processed as above. Carboxymethyl cysteine (CMC)-containing peptides, were neutralized with FA $(5 \mu \mathrm{l})$ and sequenced via parent ion discovery trigged by the CMC immonium ion (134.02 $\pm 0.05 \mathrm{mDa}$ ) as reported previously (33). Biotinylated peptides were sequenced with data-dependent acquisition after capture with streptavidin agarose beads. Ten-microliter aliquots of each final solution were injected into the CapLC-Q-TOF system.

Analysis of the Cys ${ }^{296}-C_{-} y s^{310}$ disulfide bond formation in Akt1/PKB $\alpha$ after treatment with S-nitrosoglutathione. Inactive Akt1/PKB $\alpha(10 \mu \mathrm{g}, 10 \mu \mathrm{l}, 0.18 \mathrm{nmol})$ and freshly prepared GSNO (5 $\mu 1,250 \mathrm{nmol}, \mathrm{PBS}, \mathrm{pH} 8.0)$ were stirred in an Eppendorf tube $(0.6 \mathrm{ml})$ in the dark at room temperature for $1 \mathrm{~h}$. Separation of Akt1/PKB $\alpha$ and GSNO was performed with acetone/water $(70 \%)$ as above. The kinase pellet was resuspended in PBS $(10 \mu \mathrm{l})$, and SDS sample buffer (10 $\mu \mathrm{l}$ with iodoacetamide, $20 \mathrm{nmol}$ ) was added. The cysteine alkylation was performed at room temperature for $15 \mathrm{~min}$. The protein samples were separated with SDS-PAGE Ready gels and digested as above. Aliquots of the final solution $(10 \mu \mathrm{l})$ were injected into the CapLC-Q-TOF system.

Measurement of the free and disulfide bonded Cys ${ }^{296}$ in Akt1/PKB $\alpha$ from soleus muscle of burned rats. Soleus muscle lysates from rats with third degree burn $(40 \%$ TBSA) were prepared as previously described $(29,33)$. The lysates $(\sim 10 \mathrm{mg} / \mathrm{ml}$ total proteins) were diluted to $\sim 3-5 \mathrm{mg}$ protein $/ \mathrm{ml}$ protein with PBS, and filtered through $0.22-\mu \mathrm{m}$ membranes. Immunoprecipitation was performed as follows. Anti-Akt1/PKB $\alpha \mathrm{mAb}$ (clone AW24, $5 \mu \mathrm{g}$; Upstate) and prewashed protein $\mathrm{G}$ agarose beads (50 $\mu \mathrm{l}$, packed) were kept at $4^{\circ} \mathrm{C}(100 \mu \mathrm{l}$ of PBS) for $1 \mathrm{~h}$ under gentle stirring. Without washing the beads, the soleus lysates $(5 \mathrm{ml})$ were added and stirring was continued for an additional $90 \mathrm{~min}$. Non-specific proteins were removed by washing with PBS (3X), Laemmli sample buffer (50 $\mu \mathrm{l}, \mathrm{pH} 8)$ containing HPDP-Biotin $(400 \mu \mathrm{M})$ was added and the mixtures were maintained at $95^{\circ} \mathrm{C}$ for $5 \mathrm{~min}$. The procedures for SDS-PAGE separation and in-gel trypsin digestion were the same as described above.

The burn injury protocol was approved by the Committee on Research Animal Care and Use of the Massachusetts General Hospital (MGH). The MGH animal care facility is accredited by the Association for Assessment and Accreditation of Laboratory Animal Care.

LC-MS/MS analysis. All experiments were performed using a Waters CapLC-Q-TOF ${ }^{\text {micro }}$ system (Waters Corporation, Milford, MA, USA) as previously described $(32,33)$. An analytical column (75 mm ID x150 mm, C18 PepMap300, $5 \mathrm{~mm}$, LC Packings) was used to connect the stream select module of the CapLC with the voltage supply adapter for ESI. Peptide mixtures were loading onto the precolumn (C18 resin) at a flow rate of $15 \mu \mathrm{l} / \mathrm{min}$. Dead volume from the CapLC injector to the precolumn was measured to be $\sim 1.5 \mu \mathrm{l}$. After washing with mobile phase $\mathrm{C}$ (auxiliary pump, $0.1 \%$ formic acid in water/ACN, 2\% ACN) for 2 min, the trapped peptides were back-washed from the precolumn onto the analytical column using the 10-position stream switching valve. Freshly prepared mobile phases $A$ and $C$ were sonicated under vacuum for $\sim 25 \mathrm{~min}$, and mobile phase B was treated in this way for $5 \mathrm{~min}$. The mobile phases were degassed every week, and the CapLC pumps were wet primed for 20 cycles. A linear gradient was used to elute the peptide mixture from mobile phase $\mathrm{A}(0.1 \% \mathrm{FA}$ in water/ACN, $2 \% \mathrm{ACN})$ to mobile phase $\mathrm{B}$ (0.1\% FA in ACN). The gradient was segmented as follow: isocratic elution with $2 \% \mathrm{~B}$ for $3 \mathrm{~min}$, increasing B from 2 to $70 \%$ (3-40 $\mathrm{min})$, isocratic elution with $70 \% \mathrm{~B}(40-45 \mathrm{~min})$ and decreasing B from 70 to $2 \%$ (over $2 \mathrm{~min}$ ). The injector syringe $(25 \mu \mathrm{l})$ was washed with degassed mobile phase A, and the injection volume was set as full loop mode $(10 \mu \mathrm{l})$. The gradient flow rate was set at $1.5 \mu \mathrm{l} / \mathrm{min}$ before the $16 / 1$ Nanotee splitter and the pressure drop from the analytical column was $\sim 800 \mathrm{psi}$. The pressure drop (or the flow splitting ratio) was adjusted and maintained with $20 \mu \mathrm{m}$ ID capillary tubing at the waste outlet position of the Nanotee splitter. The gradient flow rate was $\sim 95 \mathrm{nl} / \mathrm{min}$. The electrospray voltage was set to $\sim 3,000 \mathrm{~V}$ to obtain an even ESI plume at the beginning of the gradient (high water content). As a routine sensitivity check, the PicoTip Emitter position and other 
parameters were adjusted to achieve $\sim 45$ counts/sec for the capillary tubing background peak (m/z 429). Sample cone and extraction cone voltages were set at 45 and $3 \mathrm{~V}$, respectively. The instrument was operated in positive ion mode with the electrospray source maintained at $90^{\circ} \mathrm{C}$. The instrument was calibrated with synthetic human $\left[\mathrm{Glu}^{1}\right]$-fibrinopeptide $\mathrm{B}$ (100 fmol/ $\mu \mathrm{l}$ in acetonitrile/water, 10:90, 0.1\% formic acid, $\mathrm{v} / \mathrm{v}$ ) at an infusion rate of $1 \mu \mathrm{l} / \mathrm{min}$ in TOF MS/MS mode. The peptide was selected at $\mathrm{m} / \mathrm{z} 785.8$ and focused into the collision cell containing argon gas at $\sim 3 \times 10^{-5}$ Torr; the collision energy was set at $35 \mathrm{~V}$. Instrument resolution for the [Glu ${ }^{1}$-fibrinopeptide B parent ion, $\mathrm{m} / \mathrm{z} 785.84$, was found to be 5,250 FWHM. All data were acquired and processed using MassLynx 4.1 software. For parent ion discovery triggered by the CMC immonium ion $(134.02 \pm 0.03 \mathrm{Da})$, the survey low and high collision energies were set at 5 and $30 \mathrm{~V}$, respectively. MS survey data were collected in continuum mode over the $\mathrm{m} / \mathrm{z}$ 100-1,200 range. Data-dependent acquisition (DDA) was set from 450 to $1,500 \mathrm{~m} / \mathrm{z}$ for the biotinylated peptides. Scan time was in the range of 1.9-3.8 sec (depending upon sample conditions), and the inter-scan delay was $0.1 \mathrm{sec} . \mathrm{MS}$ to MS/MS switch criteria were dependent upon the reporter ion intensity ( 5 counts/sec) and detection window (2.3 Da, charge status). The instrument was switched from MS/MS back to MS after $5 \mathrm{sec}$ without intensity restriction.

Evaluation of the S-nitrosylated cysteine site. Confirmations of the S-nitrosylation sites were performed by the following three step procedure. i) For parent ion discoveries by continuum MS survey, the peptide mass tolerance was 0.2 Da for the CMC immonium ion. Under these conditions, only a few false positive ions were observed and these were eliminated manually from the expected CMC parent ion list. ii) The positively discovered parent ions were analyzed with PepSeq of MassLynx V4.1 software; oxidation of methionine was searched as a variable modification. iii) For peptides, with MS/MS scores <35, manual interpretations of candidate parent ions were performed with the following procedure: continuum MS/MS spectra were smoothed, the upper $80 \%$ was centroided and cysteine residues were confirmed with three different thiol-specifically derivatized y ions. Cysteine residue monoisotopic mass $\mathrm{C}_{3} \mathrm{H}_{5} \mathrm{NOS}=103.01 \mathrm{Da}$ was replaced with $\mathrm{CMC}$ residue monoisotopic mass $\mathrm{C}_{5} \mathrm{H}_{7} \mathrm{NO}_{3} \mathrm{~S}=161.01 \mathrm{Da}, \mathrm{HPDP}-$ Biotin derivatized adduct residue monoisotopic mass $\mathrm{C}_{22} \mathrm{H}_{37} \mathrm{~N}_{5} \mathrm{O}_{4} \mathrm{~S}_{3}=531.20$ Da and Iodoacetyl-LC-Biotin derivatized adduct residue monoisotopic mass $\mathrm{C}_{21} \mathrm{H}_{35} \mathrm{~N}_{5} \mathrm{O}_{4 \mathrm{~S} 2}=485.21 \mathrm{Da}$, respectively.

\section{Results and Discussion}

It has been reported that NO production is elevated by stressors such as burn injury and in patients with type 2 diabetes (29-41). It has also been shown that the $\mathrm{Cys}^{297}-\mathrm{Cys}^{311}$ disulfide bond in the critical kinase activation loop of Akt1/PKB $\alpha$ may be formed in association with dephosphorylation under oxidative stress in vitro (31). Thus, we hypothesized that reversible S-nitrosylation at either $\mathrm{Cys}^{296}$ or $\mathrm{Cys}^{310}$ in the kinase active loop may be a second PTM factor which complements reversible phosphorylation at $\mathrm{Thr}^{308}$ in the regulation of kinase activity and we sought to determine how S-nitrosylation interacts with phosphorylation during the Akt1/PKB $\alpha$ activation cycle (22). To address these issues, GSNO was used as the only NO donor in a model S-nitrosylation system to randomly target the seven cysteine residues of the kinase at $\mathrm{pH}$ 8. Vicinal $\mathrm{Cys}^{296}$ and $\mathrm{Cys}^{310}$ take advantage of the $\mathrm{pKa}$ for dissociation of the thiol to thiolate, and these electron-rich thiolate groups can lead to formation of an intradomain disulfide bond. Under these conditions, intracellular free cysteine residues, and cysteines at the kinase surface without interactions or located in hydrophobic environments (i.e. high pKa), are unlikely to be affected by GSNO. In contrast, $\mathrm{Cys}^{296}$ and $\mathrm{Cys}^{310}$, which may have low $\mathrm{pKa}$ values due to weak interactions with vicinal residues inside the loop, are potential S-nitrosylation sites as predicted from the 3D structure of the kinase (19). NO donors, such as thioredoxin and thiol/disulfide oxidoreductases were excluded from the system to prevent possible interferences $(42,43)$; however, a small amount of 2-mercaptoethanol $(\sim 0.05 \% \mathrm{v} / \mathrm{v})$ was necessary to prevent oxygen effects.

The simple, but well-defined, S-nitrosylation reaction model was used to probe for particular NO acceptor sites in human Akt1/PKB $\alpha$ (inactive, $89 \%$ pure containing 2-mercaptoethanol and EGTA; Upstate) in three steps. i) Mapping of all cysteine residues with DTT reduction, Iodoacetyl-LC-Biotin alkylation and affinity capture provided relative MS ionization efficacies and charge states. ii) Detection of disulfide bonds with and without GSNO, provided an understanding of NO-mediated disulfide bond formation. The concentrations of the NO donor used here were similar to the levels used in reported studies (35-37). iii) MS/MS pinpointed the S-nitrosylated sites with three different thiol-specific derivatives. As indicated above, false-negatives may occur with the Biotin-Switch method (33), whereas false-positives are more common with the other methods; however, thiolether derivatives can be identified with MS/MS data. The findings of these studies were used to study the biological consequences of S-nitrosylation of Akt1/PKB $\alpha$ in soleus muscle from burned rats. This in vivo system was used because soleus muscle is an insulin-sensitive tissue with high levels of IRS-1.

A base peak intensity (BPI) nano-LC chromatogram of all seven affinity captured cysteine residues that were biotinylated with Iodoacetyl-LC-Biotin is shown (Fig. 1A). Cysteine residue monoisotopic mass of $\mathrm{C}_{3} \mathrm{H}_{5} \mathrm{NOS}=103.01 \mathrm{Da}$ was replaced with derivatized $\mathrm{Cys}$ residue monoisotopic mass of $\mathrm{C}_{21} \mathrm{H}_{35} \mathrm{~N}_{5} \mathrm{O}_{4} \mathrm{~S}_{2}=485.21 \mathrm{Da}$. The relative simplicity of the nano-LC chromatogram indicates the high purification efficacy for removing non-biotinylated tryptic peptides from streptavidin agarose beads. Three predominate TOF MS tryptic parent ions were identified; m/z 639.79 ( $\mathrm{T} 41, \mathrm{M}+2 \mathrm{H}^{+}=639.83$ ) eluting at $50.5 \mathrm{~min}, \mathrm{~m} / \mathrm{z} 1088.49$ (T9, $\mathrm{M}-\mathrm{CH}_{4}+2 \mathrm{H}^{+}=1088.03$ ) eluting at $51.5 \mathrm{~min}$ and $\mathrm{m} / \mathrm{z} 924.67$ $\left(\mathrm{T} 44, \mathrm{M}+3 \mathrm{H}^{+}=924.43\right)$ eluting at $53 \mathrm{~min}$ are doubly and triply charged tryptic peptides containing $\mathrm{Cys}^{296}, \mathrm{Cys}^{310}$ and $\mathrm{Cys}^{60}$, respectively. Fig. $1 \mathrm{~B}$ shows the parent ions co-eluting at $\sim 53 \mathrm{~min}$ as well as the charge state assignments. Parent ions $\mathrm{m} / \mathrm{z} 924.67\left(\mathrm{~T} 44, \mathrm{M}+3 \mathrm{H}^{+}=924.43\right)$ and $\mathrm{m} / \mathrm{z} 1386.51(\mathrm{~T} 44$, $\left.\mathrm{M}+2 \mathrm{H}^{+}=1386.14\right)$ are triply and doubly charged ions from the same tryptic peptide, ${ }^{308}$ TFCGTPEYLAPEVLEDNDYGR ${ }^{328}$, which contains $\mathrm{Cys}^{310}$. Parent ion $\mathrm{m} / \mathrm{z} 1266.09$ (T58, $\left.\mathrm{M}+3 \mathrm{H}^{+}=1266.41\right)$ is triply charged and derived from the peptide, ${ }^{437}$ YFDEEFTAQMTITPPDQDDSMECVDSER ${ }^{465}$, which 

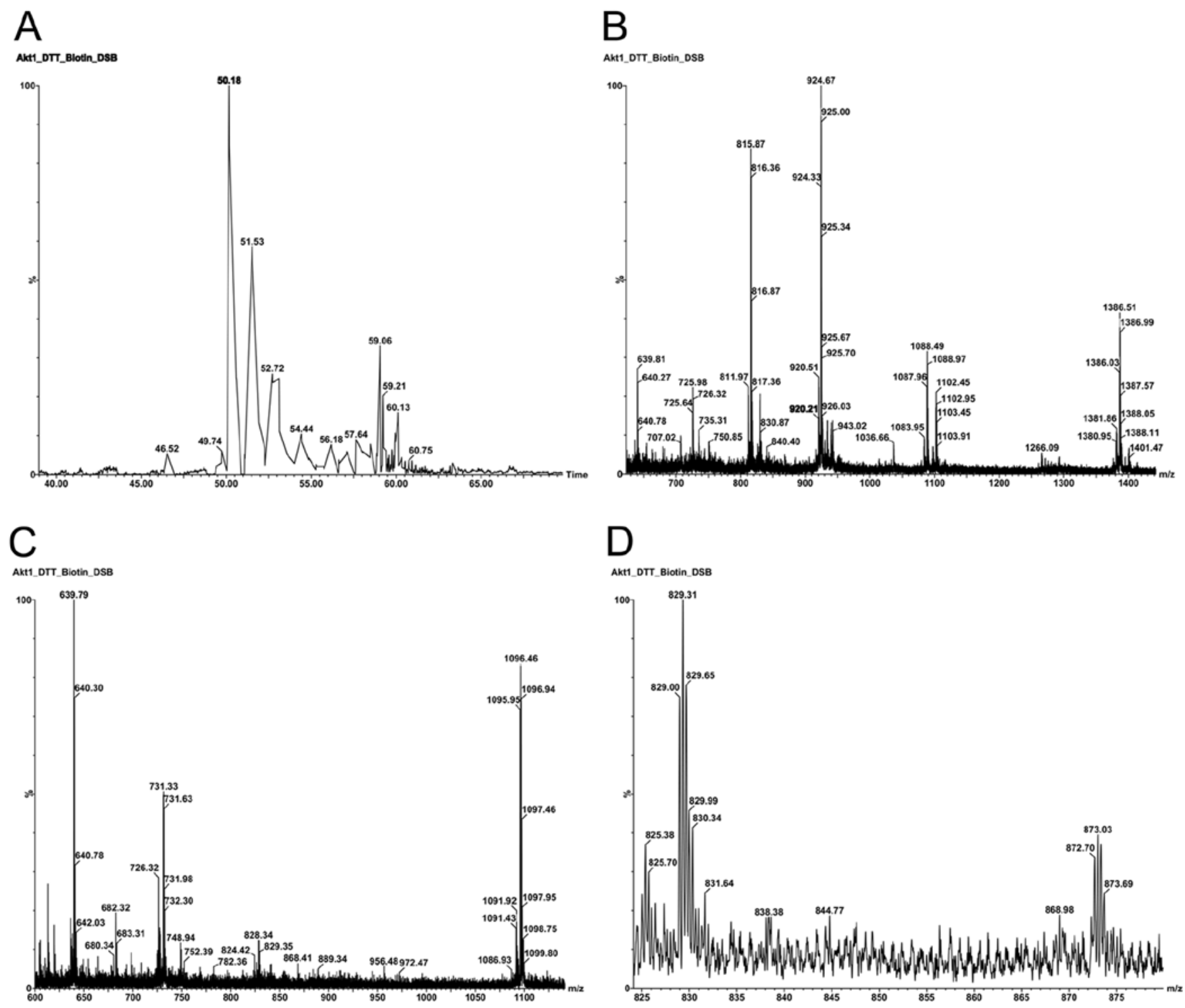

Figure 1. Mapping of cysteine residues in inactive Akt1/PKB $\alpha$. (A) Base peak intensity (BPI) nano-LC chromatogram of affinity capture of all seven cysteine residues that were biotinylated with Iodoacetyl-LC-Biotin. Sample preparation: see materials and methods section for details. Column conditions: $75 \mathrm{~mm}$ ID x150 mm, C18 PepMap300, $5 \mathrm{~mm}$, under linear gradient conditions at a flow rate $95 \mathrm{nl} / \mathrm{min}$. (B) TOF MS analysis of parent ions co-eluted at retention time of $\sim 53 \mathrm{~min}$. Parent ions $\mathrm{m} / \mathrm{z} 924.67$ and 1386.51 are triply and doubly charged ions from the same tryptic peptide ${ }^{308}$ TFCGTPEYLAPEVLEDNDYGR ${ }^{328}$ which contains $\mathrm{Cys}^{310}$. Parent ion m/z 1266.09 is a triply charged ion from the tryptic peptide, ${ }^{437}$ YFDEEFTAQMTITPPDQDDSMECVDSER ${ }^{465}$, which contains $\mathrm{Cys}^{460}$. Parent ion $\mathrm{m} / \mathrm{z} 815.87$ is a doubly charged ion derived from the tryptic peptide, ${ }^{77} \mathrm{CLQWTTVIER}^{86}$, which contains Cys ${ }^{77}$. The parent ion at $\mathrm{m} / \mathrm{z} 1088.49$ results from $\mathrm{CH}_{4}$ neutral loss from m/z 1096.46 as shown in C. (C) TOF MS analysis of parent ions co-eluting at retention time of $\sim 50.8$ min. Parent ions $\mathrm{m} / \mathrm{z} 731.33$ and 1096.46 are triply and doubly charged ions from the same tryptic peptide, ${ }^{49}$ ESPLNNFSVAQCQLMK $^{64}$, which contains Cys ${ }^{60}$. Parent ion $\mathrm{m} / \mathrm{z} 639.79$ is doubly charged and is derived from tryptic peptide, ${ }^{290}$ ITDFGLCK $^{297}$, which contains Cys ${ }^{296}$. (D) TOF MS analysis of parent ions co-eluting at retention time of $\sim 53.5 \mathrm{~min}$. Parent ion $\mathrm{m} / \mathrm{z} 829.00$ is triply charged and derived from tryptic peptide, ${ }^{329}$ AVDWWGLGVVMYEMMCGR ${ }^{346}$, which contains $\mathrm{Cys}^{344}$. Parent ion m/z 872.70 is triply charged and derived from tryptic peptide, ${ }^{223} \mathrm{LCFVMEYANGGELFFHLSR}^{241}$, which contains $\mathrm{Cys}^{224}$.

contains $\mathrm{Cys}^{460}$. Parent ion $\mathrm{m} / \mathrm{z} 815.87\left(\mathrm{~T} 11, \mathrm{M}+2 \mathrm{H}^{+}=815.93\right)$ is doubly charged from the peptide, ${ }^{77}$ CLQWTTVIER ${ }^{86}$, which contains $\mathrm{Cys}^{77}$. Parent ion $\mathrm{m} / \mathrm{z} 1088.49$ resulted from $\mathrm{CH}_{4}$ neutral loss from $\mathrm{m} / \mathrm{z}$ 1096.48. Fig. 1C shows TOF MS parent ions that co-eluted at $\sim 50.8 \mathrm{~min}$; chromatographic peak tailing the most intense peak at $50.5 \mathrm{~min}$. Parent ions $\mathrm{m} / \mathrm{z} 731.33$ (T9, $\left.\mathrm{M}+3 \mathrm{H}^{+}=731.03\right)$ and $\mathrm{m} / \mathrm{z} 1096.46\left(\mathrm{~T} 9, \mathrm{M}+2 \mathrm{H}^{+}=1096.04\right)$ are triply and doubly charged ions from the same tryptic peptide, ${ }^{49}$ ESPLNNFSVAQCQLMK ${ }^{64}$, which contains Cys $^{60}$. Parent ion $\mathrm{m} / \mathrm{z} 639.79\left(\mathrm{~T} 41, \mathrm{M}+2 \mathrm{H}^{+}=639.83\right)$ is a doubly charged ion from the tryptic peptide, ${ }^{290}$ ITDFGLCK ${ }^{297}$, which contains $\mathrm{Cys}^{296}$. Fig. 1D shows the TOF MS parent ions that co-eluted at $\sim 53.5 \mathrm{~min}$. Parent ion $\mathrm{m} / \mathrm{z} 829.00$ (T45, $\left.\mathrm{M}+3 \mathrm{H}^{+}=829.05\right)$ is triply charged and derived from the tryptic peptide, ${ }^{329} \mathrm{AVDWWGLGVVMYEMMCGR}{ }^{346}$, which contains $\mathrm{Cys}^{344}$. Parent ion $\mathrm{m} / \mathrm{z} 872.70\left(\mathrm{~T} 32, \mathrm{M}+3 \mathrm{H}^{+}=872.43\right)$ is triply charged and derived from the tryptic peptide, ${ }^{223}$ LCFVMEYANGGELFFHLSR ${ }^{241}$, which contains Cys ${ }^{224}$. No doubly charged T58, T45 or T32 ions were observed. It is clear that the ionization efficacies for the peptides containing $\mathrm{Cys}^{296}\left(\mathrm{M}+2 \mathrm{H}^{+}\right), \mathrm{Cys}^{310}\left(\mathrm{M}+2 \mathrm{H}^{+}\right.$and $\left.\mathrm{M}+3 \mathrm{H}^{+}\right), \mathrm{Cys}^{60}\left(\mathrm{M}+2 \mathrm{H}^{+}\right.$ and $\left.\mathrm{M}+3 \mathrm{H}^{+}\right)$and $\mathrm{Cys}^{77}\left(\mathrm{M}+2 \mathrm{H}^{+}\right)$are much higher than for the triply charged peptides containing $\mathrm{Cys}^{460}\left(\mathrm{M}+3 \mathrm{H}^{+}\right)$, Cys334 $\left(\mathrm{M}+3 \mathrm{H}^{+}\right)$and $\mathrm{Cys}^{224}\left(\mathrm{M}+3 \mathrm{H}^{+}\right)$under the same conditions. 

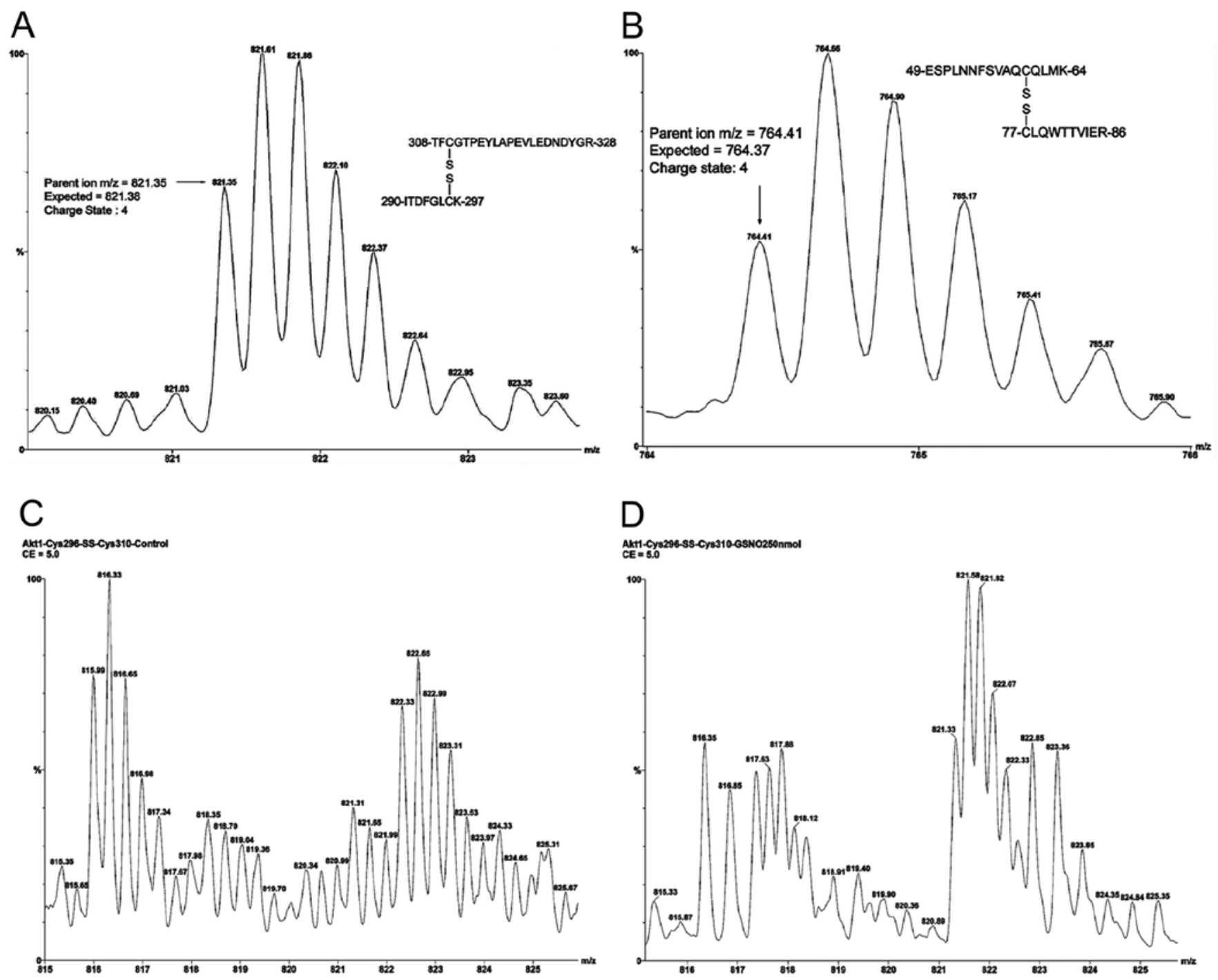

Figure 2. Detections of two intradomain disulfide bonds in $\mathrm{Akt1} / \mathrm{PKB} \alpha$. (A) Detection of intradomain $\mathrm{Cys}^{296}$ - $\mathrm{Cys}^{310}$ disulfide bond in the kinase loop. Inactive Akt1/PKB $\alpha(10 \mu \mathrm{g})$ was treated with GSNO and iodoacetamide $(50 \mu \mathrm{M})$ in Laemmli sample buffer as in D. In-gel trypsin digestion was performed after SDS-PAGE separation (4-15\% Tris-HCl). Monoisotopic parent ion at $\mathrm{m} / \mathrm{z} 821.35$, charge state 4 . Expected quadruply charged disulfide linked Cys ${ }^{296}$ and Cys ${ }^{310}$ containing the peptide at $\mathrm{m} / \mathrm{z}$ 821.38. (B) Detection of the intradomain $\mathrm{Cys}^{60}-\mathrm{Cys}^{77}$ disulfide bond in the PH domain. Monoisotopic parent ion at $\mathrm{m} / \mathrm{z} 764.41$, charge state 4. Expected quadruply charged disulfide bond linked $\mathrm{Cys}^{60}$ and $\mathrm{Cys}^{77}$-containing peptide at $\mathrm{m} / \mathrm{z}$ 764.37. (C) Free thiol state of Cys ${ }^{310}$ in the kinase loop without NO donor. The triply charged parent ion $\mathrm{m} / \mathrm{z}$ 815.99: ${ }^{308}{ }^{8}$ FCGTPEYLAPEVLEDNDYGR ${ }^{328}$ (expected: $\mathrm{m} / \mathrm{z} 816.03$, CAM derivative) represents the completely free thiol state of $\mathrm{Cys}^{310}$, while the triply charged $\mathrm{m} / \mathrm{z} 821.31$ is not from disulfide linked $\mathrm{Cys}^{296}$-Cys ${ }^{310}$ dipeptides (expected charge state 4). The

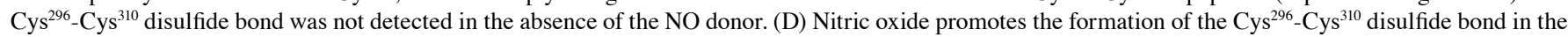
kinase loop. Inactive Akt1/PKB $\alpha(10 \mu \mathrm{g})$ was treated with GSNO (250 nmol, $50 \mu 1 \mathrm{PBS}, \mathrm{pH} 8.0,1 \mathrm{~h}$ at room temperature in dark) prior to alkylation with iodoacetamide and SDS-PAGE. The doubly charged $\mathrm{m} / \mathrm{z} 816.35$ ion is not from a Cys $\mathrm{Cy}^{310}$-containing tryptic peptide (expected charge state 3 ), and quadruply charged $\mathrm{m} / \mathrm{z} 821.33$ occurs at the expense of diminished triply charged $\mathrm{Cys}^{310}$ peptide. The free thiol of $\mathrm{Cys}^{310}$ is completely converted into the disulfide bond with Cys ${ }^{296}$.

When Akt1/PKB $\alpha$ was treated with GSNO without cleavage of disulfide bonds and the free cysteine residues were alkylated with iodoacetamide, two intradomain disulfide bonds were identified: $\mathrm{Cys}^{60}-\mathrm{Cys}^{77}$ in the PH domain and $\mathrm{Cys}^{296}-\mathrm{Cys}^{310}$ in the kinase active loop. The monoisotopic parent ion with $\mathrm{m} / \mathrm{z}$ 821.35, shown in Fig. 2A, represents two tryptic peptides containing the $\mathrm{Cys}^{296}{ }^{2} \mathrm{Cys}^{310}$ disulfide bond in the kinase loop. The isotopic peaks at $\mathrm{m} / \mathrm{z} 821.61$ and $\mathrm{m} / \mathrm{z} 821.35$ are attributed to the $\mathrm{M}+1$ and $\mathrm{M}+0$ ions. A mass difference of $0.26 \mathrm{Da}$ (expected $0.25 \mathrm{Da}$ ) indicated four positive charges: two at $\mathrm{N}$-terminals and two at side chains of the C-terminals of the dipeptides. The expected quadruply charged disulfide bond linked $\mathrm{Cys}^{296}$ and $\mathrm{Cys}^{310}$-containing peptides (T41-SS-T44, M+4H+) were calculated to be $\mathrm{m} / \mathrm{z} 821.38[(894.45+2387.06+4) / 4]$.
The monoisotopic parent ion with $\mathrm{m} / \mathrm{z}$ 764.41, shown in Fig. 2B, represents the two tryptic peptides containing the $\mathrm{Cys}^{60}-\mathrm{Cys}^{77}$ disulfide bond in the PH domain. The quadruply charged state is calculated as $\mathrm{m} / \mathrm{z} 764.66(\mathrm{M}+1)-764.41$ $(\mathrm{M}+0)=0.25$ which indicates four positive proton charges. The quadruply charged disulfide bond linked $\mathrm{Cys}^{60}$ and $\mathrm{Cys}^{77}$ containing peptides (T9-SS-T11, $\mathrm{M}+4 \mathrm{H}^{+}$) are calculated as $\mathrm{m} / \mathrm{z} 764.37[(1806.86+1246.63+4) / 4]$. Without GSNO treatment, only the $\mathrm{Cys}^{60}$-Cys ${ }^{77}$ disulfide bond was detected. The mass accuracies for the two measurements were found to be 36 ppm (Cys ${ }^{296}-\mathrm{Cys}^{310}$ disulfide bond linked dipeptides) and $78 \mathrm{ppm}\left(\mathrm{Cys}^{60}{ }_{-} \mathrm{Cys}^{77}\right.$ disulfide bond linked dipeptides). The impact of GSNO on $\mathrm{Cys}^{296}-\mathrm{Cys}^{310}$ disulfide bond formation is demonstrated in Fig. 2C and D. The S-nitrosylation reac- 
Table I. Characterization of the thiol-specifically modified Akt1/PKB $\alpha$ peptide ${ }^{290}{ }^{2 T D F G L C K}{ }^{297}$.

\begin{tabular}{lcccc}
\hline Chemical derivatives & Parent calc. & Parent found & y2 ion calc. & y2 ion found \\
\hline CMC & 953.45 & 953.42 & 308.13 & 308.17 \\
HPDP-Biotin & 1323.64 & 1323.68 & 678.32 & 678.29 \\
Acetyl-LC-Biotin & 1277.65 & 1277.58 & 632.33 & 632.38 \\
\hline
\end{tabular}

tion without GSNO (Fig. 2C) shows the triply charged tryptic peptide, ${ }^{308}$ TFCGTPEYLAPEVLEDNDYGR ${ }^{328}$, [carboxyamidomethyl cysteine (CAM) derivative] containing $\mathrm{Cys}^{310}$ at $\mathrm{m} / \mathrm{z} 815.99$ (expected monoisotopic parent ion, 816.03). The observed $\mathrm{M}+1$ isotopic peak was at $\mathrm{m} / \mathrm{z}$ 816.33. The difference between the isotopic $\mathrm{M}+1$ and $\mathrm{M}+0$ peak of $0.34 \mathrm{Da}$ indicates three proton charges. In contrast, the triply charged ions at $\mathrm{m} / \mathrm{z} 821.31$ and 821.65 (difference $=0.31 \mathrm{Da}$ ) do not represent the quadruply charged $\mathrm{Cys}^{296}-\mathrm{Cys}^{310}$ dipeptides in Fig. 2C. The triply charged $\mathrm{Cys}^{310}$-containing peptide was found to be totally absent with GSNO treatment as shown in Fig. 2D. The doubly charged ions at $\mathrm{m} / \mathrm{z} 816.35$ and 816.85 (difference $=0.50 \mathrm{Da})$ are not related to the triply charged tryptic peptide ${ }^{308}$ TFCGTPEYLAPEVLEDNDYGR ${ }^{328}$ (CAM derivative) containing $\mathrm{Cys}^{310}$ at $\mathrm{m} / \mathrm{z} 815.99$ as shown in Fig. 2C. In contrast, the ions at $\mathrm{m} / \mathrm{z} 821.33$ and 821.58 (difference $=0.25 \mathrm{Da}$ ) are indeed from quadruply charged $\mathrm{Cys}^{296}$-Cys ${ }^{310}$-linked dipeptides. Since quadruply charged $\mathrm{Cys}^{296}$-Cys ${ }^{310}$-linked dipeptides are formed at the expense of triply charged $\mathrm{Cys}^{310}$-containing peptide after GSNO treatment, it is obvious that S-nitrosylation and disulfide bond formation occur simultaneously in the kinase loop.

We next sought to determine which cysteine residue is the $\mathrm{NO}$ acceptor that initializes $\mathrm{Cys}^{296}{ }_{-} \mathrm{Cys}^{310}$ disulfide bond formation. There are three possibilities for the two cysteine residue thiol states: single S-nitrosothiol, double S-nitrosothiols and nitroxyl disulfide. The last case (nitroxyl disulfide) can be ruled out from the list, since the expected net mass increases of $28 \mathrm{Da}$ (NO - 2H $=30-2 \mathrm{Da}$ ) were not observed for the corresponding dipeptides. The second case, double S-nitrosothiols of $\mathrm{Cys}^{296}$ and $\mathrm{Cys}^{310}$, may occur if both pKa values are acidic inside the kinase loop. The Biotin-Switch method was used to identify the S-nitrosothiol within the loop under gentle reaction conditions (GSNO $250 \mathrm{nmol}, 1 \mathrm{~h}$ ). In addition, two other thiol-specific reagents, iodoacetic acid and Iodoacetyl-LC-Biotin (leaving molecule: HI, fast and quantitative), were evaluated.

Table I shows the expected results of $\mathrm{Cys}^{296} \mathrm{~S}$-nitrosylation in the kinase loop with the three different chemical modifications. The resulting S-nitrosylated Cys was reduced with ascorbate and then derivatized with iodoacetic acid to afford the CMC derivative (the Cys residue with a monoisotopic mass $\mathrm{C}_{3} \mathrm{H}_{5} \mathrm{NOS}=103.01 \mathrm{Da}$ was replaced by the CMC residue with a monoisotopic mass $\mathrm{C}_{5} \mathrm{H}_{7} \mathrm{NO}_{3} \mathrm{~S}=161.01 \mathrm{Da}$ ) for sequence analysis. The CMC derivative of the y2 ion of the doubly charged tryptic peptide, ${ }^{290}{ }^{2 T D F G L C K}{ }^{297}$, was confirmed at $\mathrm{m} / \mathrm{z} 308.17$ (expected $308.13=161.01+145.10+$ 2.02). The Cys HPDP-Biotin adduct (Cys residue monoisotopic mass $\mathrm{C}_{3} \mathrm{H}_{5} \mathrm{NOS}=103.01 \mathrm{Da}$ was replaced with the adduct residue monoisotopic mass $\mathrm{C}_{22} \mathrm{H}_{37} \mathrm{~N}_{5} \mathrm{O}_{4} \mathrm{~S}_{3}=531.20 \mathrm{Da}$ ) was used for sequence analysis. The corresponding y2 ion of the
Biotin-HPDP derivatized, ${ }^{290}$ ITDFGLCK ${ }^{297}$, was confirmed at $\mathrm{m} / \mathrm{z} 678.29$ (expected $678.32=531.20+145.10+2.02$ ). The Cys Iodoacetyl-LC-Biotin adduct (Cys residue monoisotopic mass $\mathrm{C}_{3} \mathrm{H}_{5} \mathrm{NOS}=103.01 \mathrm{Da}$ was replaced with adduct residue monoisotopic mass $\mathrm{C}_{21} \mathrm{H}_{35} \mathrm{~N}_{5} \mathrm{O}_{4} \mathrm{~S}_{2}=485.21 \mathrm{Da}$ ) was used for peptide sequence analysis. The corresponding y2 ion of Iodoacetyl-LC-Biotin derivatized, ${ }^{290}{ }^{\text {ITDFGLCK }}{ }^{297}$ was confirmed at $\mathrm{m} / \mathrm{z} 632.38$ (expected $632.33=485.21+145.10$ + 2.02). Since the $y 2$ ions of ${ }^{296} \mathrm{Cys}-\mathrm{Lys}^{297}$ produced with the three different derivatization procedures were unambiguously observed it is likely that $\mathrm{Cys}^{296}$ is a favorable S-nitrosylation site under the conditions used. Although studies with mutated $\mathrm{Akt1} / \mathrm{PKB} \alpha\left(\mathrm{Cys}^{224}\right)$ indicated that $\mathrm{Cys}^{224}$ is a major S-nitrosylation acceptor site in vitro (28), the biological role of S-nitrosylated $\mathrm{Cys}^{224}$ in kinase regulation needs to be further explored. In the current study it was determined that significant S-nitrosylation of $\mathrm{Cys}^{224}$ is improbable, since using the three alkylation approaches and trypsin digestion, the levels of positive ionization of $\mathrm{Cys}^{224}$-containing peptides were below the level of detection. This failure in detection of S-nitrosylated $\mathrm{Cys}^{224}$ may be a false-negative under our experimental conditions and clearly warrants further investigation. Nevertheless, our findings clearly demonstrate that S-nitrosylated Cys ${ }^{296}$ is directly relevant to the kinase activation regulation cycle.

One possible explanation for the kinetics of $\mathrm{Cys}^{296}-\mathrm{Cys}^{310}$ disulfide bond formation in the kinase loop may be that there is a high kinetic barrier without GSNO. Due to its highly labile nature (44), S-nitrosylated $\mathrm{Cys}^{296}$, which forms rapidly in the presence of GSNO, may function as an intermediate state. Since this intermediate is likely to have a lower kinetic barrier for $\mathrm{Cys}^{296}{ }_{-} \mathrm{Cys}^{310}$ disulfide bond formation, the overall speed of the reaction should increase greatly. It has been reported that trans-nitrosylation reactions between vicinal thiols can occur and accelerate disulfide bond formation (45). The well characterized $\mathrm{Cys}^{296}-\mathrm{Cys}^{310}$ disulfide bond can be used as a signature peptide for detection of S-nitrosylation of Cys ${ }^{296}$ after immunoprecipitation. The separation of tryptic peptide mixtures with our nano-LC interfaced Q-TOF ${ }^{\text {micro }}$ is demonstrated in Fig. 3 (bottom panel). The extracted mass ion peak $\mathrm{m} / \mathrm{z}$ 821.62, as shown in Fig. 3 (top panel), is the $\mathrm{M}+1$ isotopic peak of the quadruply charged dipeptides (the most intense isotopic peak due to a high number of carbon atoms).

The in vitro system allowed us to determine conditions that are favorable for evaluation of S-nitrosylation of Cys ${ }^{296}$ by MS/MS and was useful for studying the mechanism of intradomain disulfide bond formation. The reason for using inactive $\mathrm{Akt} 1 / \mathrm{PKB} \alpha$ (unphosphorylated) in these studies was to find possible S-nitrosylation sites in relationship with the following published data: i) Akt1/PKB $\alpha$ undergoes transient phosphorylation/dephosphorylation which regulates the 


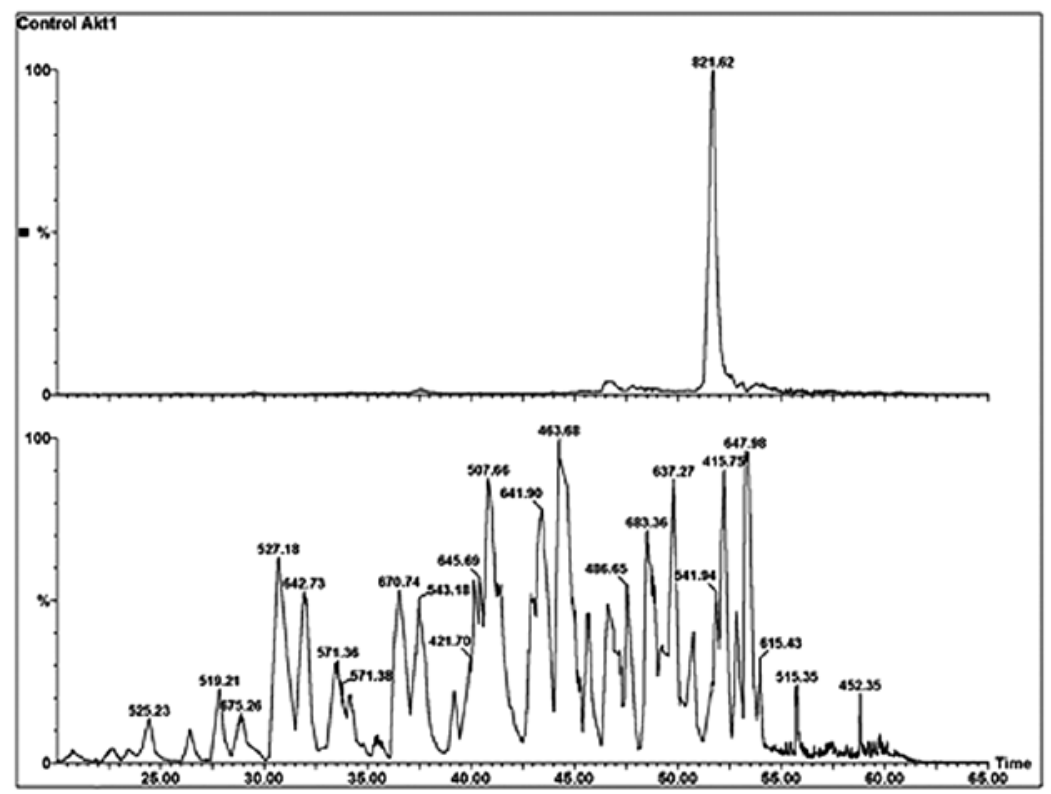

Figure 3. Nano-LC chromatogram of tryptic peptides of Akt1/PKB $\alpha$ and MS ion 821.62 chromatogram of soleus muscle. Top panel: mass ion chromatogram of the dipeptides $\mathrm{m} / \mathrm{z}$ 821.62: $\mathrm{M}+1$ isotopic peak of the quadruply charged dipeptides (intensity of M+0 monoisotopic peak is lower than M+1). Bottom panel: BPI chromatogram of the Akt1/PKB $\alpha$ tryptic peptides after immunoprecipitations and in-gel digestion from nano-LC interfaced with Q-TOF tandem mass spectrometry.

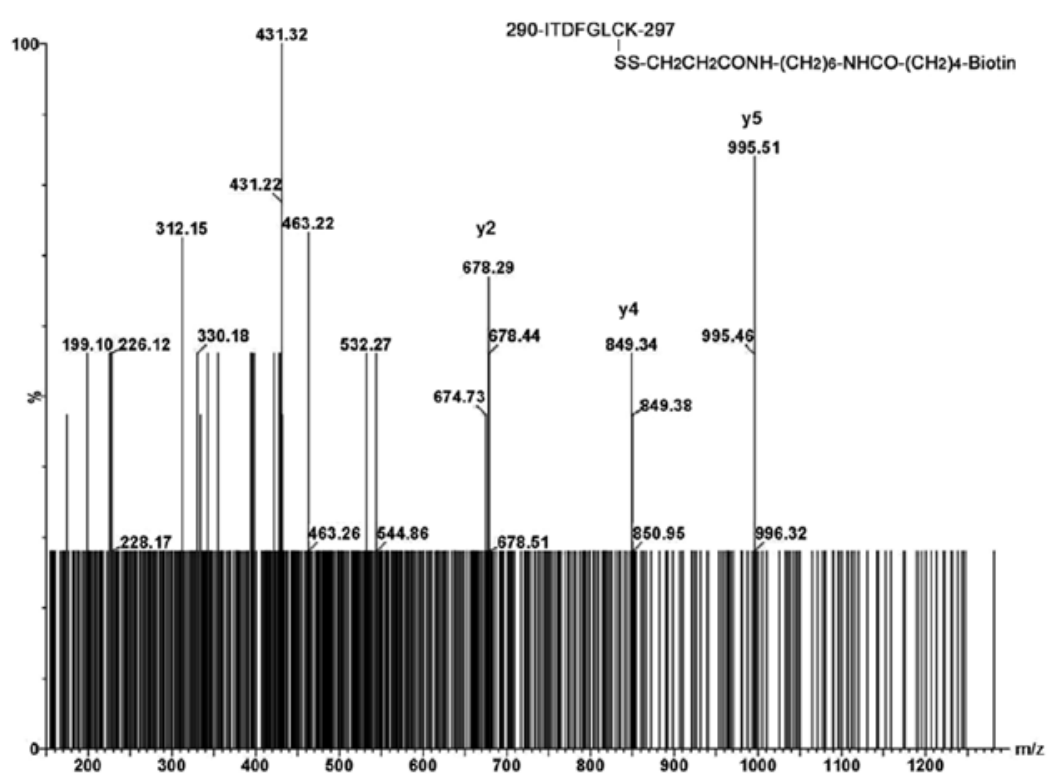

Figure 4. MS/MS sequence analysis of biotinylted free $\mathrm{Cys}^{296}$ peptide of Akt1/PKB $\alpha$ after burn injury. Rat soleus muscle lysates (30 mg total protein) were treated with anti-Akt1/PKB $\alpha \mathrm{mAb}$ and in-gel biotination was performed with HPDP-Biotin. Parent ion $\mathrm{m} / \mathrm{z} 662.84\left(\mathrm{M}+2 \mathrm{H}^{+}\right.$, expected 662.82) was sequenced. Cys residue monoisotopic mass $\mathrm{C}_{3} \mathrm{H}_{5} \mathrm{NOS}=103.01 \mathrm{Da}$ is replaced with the adduct residue monoisotopic mass $\mathrm{C}_{22} \mathrm{H}_{37} \mathrm{~N}_{5} \mathrm{O}_{4} \mathrm{~S}_{3}=531.20$ Da. A low sequence score 18 was obtained from the parent ion with $\mathrm{S} / \mathrm{N}=3$; however the critical diagnostic y2, y4 and y5 ions at $\mathrm{m} / \mathrm{z} 678.29,849.34$ and 995.51 confirmed that trace amounts of free $\mathrm{Cys}^{296}$ are present after burn injury.

kinase activity conformation cycle (22); ii) kinase disulfide bond formation, $\mathrm{Cys}^{297}-\mathrm{Cys}^{311}$, and dephosphorylation at pThr ${ }^{308}$ are induced simultaneously by $\mathrm{H}_{2} \mathrm{O}_{2}$ oxidative stress in vitro $(31)$; iii) high levels of nitric oxide production occur both after burn injury $(29,42)$ and in diabetic patients $(43)$. Previous results from our laboratory have indicated that there is S-nitrosylation at $\mathrm{Cys}^{296}$ in rat soleus muscle (33). A parent ion at $\mathrm{m} / \mathrm{z} 690.83$ containing $\mathrm{Cys}^{296}$ (T41-T42: ${ }^{290}$ ITCFGLCKEGIK $^{301}$ ) was observed with CAM immonium trigged parent ion discovery; however, MS/MS sequencing data were not obtained. As a continuation of these studies to explore S-nitrosylation in the kinase active loop, large amounts of rat soleus muscle lysate $(\sim 3-5 \mathrm{mg} / \mathrm{ml}$ total proteins, $3 \mathrm{ml}$ for each experiment, day 4 after $40 \%$ TBSA, 3rd degree burn) were used. In the present study, detailed MS/MS analyses of HPDP-biotinylated free $\mathrm{Cys}^{296}$ peptide and $\mathrm{Cys}^{296}-\mathrm{Cys}^{310}$ disulfide bound dipeptides of $\mathrm{Akt} 1 / \mathrm{PKB} \alpha$ were performed with lysates of rat soleus muscle after burn injury. The tryptic 


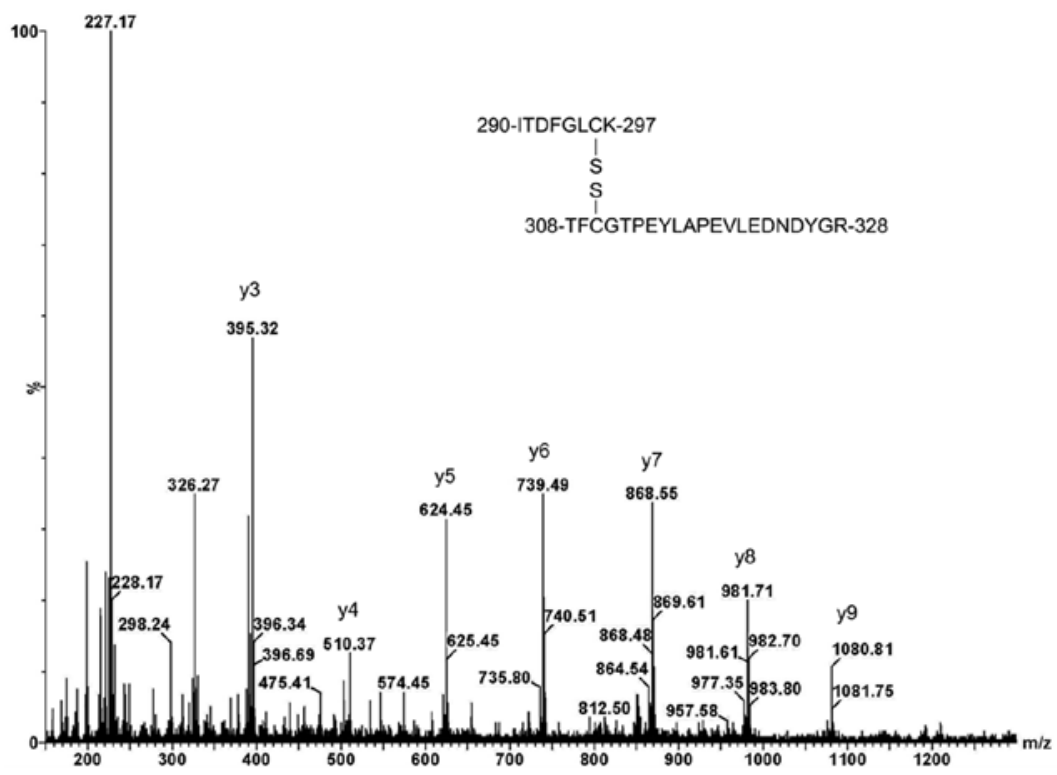

Figure 5. MS/MS sequence analysis of the $\mathrm{Cys}^{296}-\mathrm{Cys}^{310}$ disulfide-linked peptide with dephosphoryated $\mathrm{Thr}^{308}$ in soleus muscle from burned rats. Partially sequenced $\mathrm{Cys}^{296}$-Cys $^{310}$ disulfide-linked dipeptides: C-terminal y ion series ( $\mathrm{y} 3$ to y9) of $\mathrm{Cys}^{310}$-containing peptide, ${ }^{308}$ TFCGTPEYLAPEVLEDNDYGR $^{328}$, were observed from the quadruply charged parent ion (T41-SS-T44, M+4H+1 $)$.

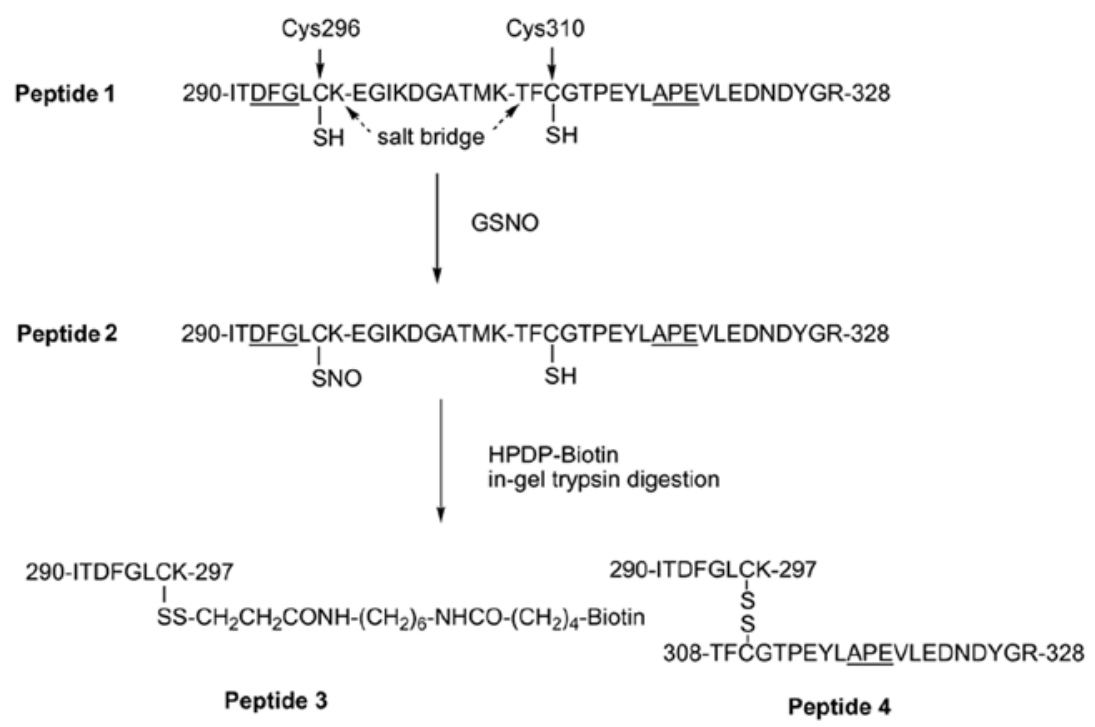

Figure 6. Proposed mechanism for Akt1/PKB $\alpha$ kinase regulation by phosphorylation and S-nitrosylation in the muscle of burned rats. Phosphorylation of $\mathrm{Thr}^{308}$ stabilizes the disordered loop structure between ${ }^{292} \mathrm{DFG}$ and $\mathrm{APE}^{319}$ via a salt bridge with $\mathrm{Lys}^{297}$ as illustrated in the loop Peptide 1, which upregulates $\mathrm{Akt1} / \mathrm{PKB} \alpha$ kinase activity. NO free radical production is increased after burn injury. A large portion of Cys ${ }^{296}$ undergoes S-nitrosylation at Cys ${ }^{296}$ (Peptide 2); however, some free $\mathrm{Cys}^{296}$ remains (Peptide 3). S-nitrosylation activates $\mathrm{Cys}^{296}-\mathrm{Cys}^{310}$ intradomain disulfide bond formation (Peptide 4). S-nitrosylation at $\mathrm{Cys}^{296}$ is associated with dephosphorylation of $\mathrm{Thr}^{308}$ and inaccessibility to the kinase site; which downregulates kinase activity.

parent ion derivatized from free Cys ${ }^{296}$ after burn injury was observed at $\mathrm{m} / \mathrm{z} 662.84\left(\mathrm{M}+2 \mathrm{H}^{+}\right.$, expected 662.82) and the MS/ MS sequence data are shown in Fig. 4. A low sequence score of 18 was obtained from the parent ion with $\mathrm{S} / \mathrm{N}=3$. However, the critical diagnostic y2, y4 and y5 ions at $\mathrm{m} / \mathrm{z} 678.29,849.34$ and 995.51 confirmed that trace amounts of free $\mathrm{Cys}^{296}$ are indeed present after intradomain disulfide bond formation induced by burn injury. In addition, partial sequencing data for $\mathrm{Cys}^{296}-\mathrm{Cys}^{310}$ disulfide-linked dipeptides are shown in Fig. 5. The C-terminal $\mathrm{y}$ ion series of $\mathrm{Cys}^{310}$-containing peptide,
${ }^{308}$ TFCGTPEYLAPEVLEDNDYGR ${ }^{328}$, was observed for the quadruply charged parent ion (T41-SS-T44, $\mathrm{M}+4 \mathrm{H}^{+}$). $\mathrm{Cys}^{296}$-Cys $^{310}$ disulfide-linked dipeptides were not observed in muscle lysates from sham-treated animals (negative controls). The chance of obtaining the MS/MS sequence using our in vivo experimental conditions is only $\sim 20-25 \%$. This indicates that one interpretable MS/MS outcome (score $>25$ ) is expected in four or five independent experiments in which three successive injections are performed. Nevertheless, these MS/MS data for peptides containing free $\mathrm{Cys}^{296}$ and $\mathrm{Cys}^{296}{ }_{-} \mathrm{Cys}^{310}$-linked 
dipeptides are sufficient to verify our hypothesis that S-nitrosylation promotes intradomain disulfide bond formation and dephosphorylation at $\mathrm{pThr}^{308}$ after burn injury as illustrated in Fig. 6. Due to its high lability of $\mathrm{Cys}^{296}$-SNO, direct identification of this species in vivo was not possible.

S-nitrosylation of $\mathrm{Akt} 1 / \mathrm{PKB} \alpha$ is a key factor for understanding the regulation of glucose transport and downstream protein synthesis. A recent study demonstrated that blockade of iNOS prevents the S-nitrosylations of Akt and IRS-1 and results in insulin resistance in vivo (46). Although it is clear that two PTMs of Akt1/PKB $\alpha$, phosphorylation at $\mathrm{Thr}^{308}$ and $\mathrm{S}$-nitrosylation at $\mathrm{Cys}^{296}$, are critical for the regulation of $\mathrm{Akt1} / \mathrm{PKB} \alpha$ activity under stress conditions, there are still many unanswered questions concerning how reversible phosphorylation/dephosphorylation and S-nitrosylation/denitrosylation modulate $\mathrm{Akt1} / \mathrm{PKB} \alpha$ activity. For example, it has been reported that the $\mathrm{Cys}^{296}-\mathrm{Cys}^{310}$ disulfide bond is present only when there is binding of substrate to the active kinase loop and phosphorylation at $\mathrm{Thr}^{308}$ (25); indicating that both disulfide bond formation as well as phosphorylation of $\mathrm{Thr}^{308}$ are important for kinase activity. In contrast, this disulfide bond was not observed under similar conditions in two studies of the ternary structure of the kinase $(19,21)$; even though, oxidative stress was shown to induce dephosphorylation of $\mathrm{pThr}^{308}$ and disulfide bond formation in the kinase loop in an in vitro study (31).

In summary, our data establish that $\mathrm{Cys}^{296}$ is an important S-nitrosylation site in the kinase loop of Akt1/PKB $\alpha$ under gentle reaction conditions: i) iodoacetic acid as previously described; ii) the HPDP-Biotin switch method; and iii) the Iodoacetyl-LC-Biotin method to ensure indirect capture of $\mathrm{Cys}^{296}$-SNO which may be undetectable with HPDP-Biotin. The corresponding derivatized y2 ions $\left({ }^{296} \mathrm{Cys}-\mathrm{Lys}{ }^{297}\right)$ in the tryptic peptide (Ile-Thr-Asp-Phe-Gly-Leu-Cys-Lys) were obtained with mass sequences to eliminate false-positive discovery. Although no other S-nitrosylated cysteine residues were detected, it is possible that S-nitrosylations at $\mathrm{Cys}^{224}$, $\mathrm{Cys}^{344}$ and $\mathrm{Cys}^{460}$ were missed due to very low ionizations (i.e., false-negative discoveries). As a consequence of S-nitrosylation at $\mathrm{Cys}^{296}$, there is rapid disulfide bond formation with vicinal $\mathrm{Cys}^{310}$ in the kinase loop, which alters kinase substrate recognition (47) as well as Akt-FOXO switch (48). This affords a stable disulfide bond linked quadruply charged parent ion at $\mathrm{m} / \mathrm{z} 821.35\left(\mathrm{M}+4 \mathrm{H}^{+}\right)$. Partial sequencing data for Cys ${ }^{296}-\mathrm{Cys}^{310}$ linked dipeptides from soleus muscle lysates indicated that burn injury is associated with both dephosphorylation of $\mathrm{pThr}^{308}$ and disulfide bond formation. These two types of PTMs may provide insights for understanding negative cooperative effects on reduced Akt/PKB kinase activity after burn injury as previously reported by our laboratory (26). Although our results have provided important mechanistic information, quantitative measurements of $\mathrm{Thr}^{308} / \mathrm{pThr}^{308}$ and free $\mathrm{Cys}^{296} /$ SNO-Cys ${ }^{296} /$ bound Cys ${ }^{296}$ in patients with burn injury and type 2 diabetes remain very challenging.

\section{Acknowledgements}

This study was supported in part by grants from the National Institutes of Health (NIGMS P50 GM21000) and Shriners Hospital for Children.

\section{References}

1. Biolo G, Fleming RY, Maggi SP, Nguye TT, Herndon DN and Wolfe RR: Inverse regulation of protein turnover and amino acid transport in skeletal muscle of hypercatabolic patients. J Clin Endocrinol Metab 87: 3378-3384, 2002.

2. Bodine SC, Stitt TN, Gonzalez M, Kline WO, Stover GL, Bauerlein R, Zlotchenko E, Scrimgeour A, Lawrence JC, Glass DJ and Yancopoulos GD: Akt/mTOR pathway is a crucial regulator of skeletal muscle hypertrophy and can prevent muscle atrophy in vivo. Nat Cell Biol 3: 1014-1019, 2001.

3. Bruning JC, Winnay J, Cheatham B and Kahn CR: Differential signaling by insulin receptor substrate 1 (IRS-1) and IRS-2 in IRS-1-deficient cells. Mol Cell Biol 17: 1513-1521, 1997.

4. Carvalho E, Rondinone $\mathrm{C}$ and Smith U: Insulin resistance in fat cells from obese Zucker rats - evidence for an impaired activation and translocation of protein kinase B and glucose transporter 4. Mol Cell Biochem 206: 7-16, 2000.

5. Araki E, Lipes MA, Patti ME, Bruning JC, Haag B, Johnson RS and Kahn CR: Alternative pathway of insulin signaling in mice with targeted disruption of the IRS-1 gene. Nature 372: 186-190, 1994.

6. Khoury W, Klausner JM, Ben-Abraham R and Szold O: Glucose control by insulin for critically ill surgical patients. J Trauma 57: 1132-1138, 2004.

7. Carter EA, Burks D, Fischman AJ, White M and Tompkins RG: Insulin resistance in thermally-injured rats is associated with post-receptor alterations in skeletal muscle, liver and adipose tissue. Int J Mol Med 14: 653-658, 2004.

8. Johan Groeneveld AB, Beishuizen A and Visser FC: Insulin: a wonder drug in the critically ill? Crit Care 6: 102-105, 2002.

9. Ikezu T, Okamato T, Yonezawa K, Tompkins RG and Martyn JA: Analysis of thermal injury-induced insulin resistance in rodents. J Biol Chem 272: 25289-25295, 1997.

10. White MF: Insulin signaling in health and disease. Science 302: 1710-1711, 2003.

11. Zhang Q, Carter EA, Ma BY, White M, Fischman AF and Tompkins RG: Molecular mechanism(s) of burn-induced insulin resistance in murine skeletal muscle: role of IRS phosphorylation. Life Sci 77: 3068-3077, 2005.

12. Ishiki M and Klip A: Minireview: recent developments in the regulation of glucose transporter-4 traffic: new signals, locations, and partners. Endocrinology 146: 5071-5078, 2005.

13. Kaneki M, Shimizu N, Yamada D and Chang K: Nitrosative stress and pathogenesis of insulin resistance. Antioxid Redox Signal 9: 1-11, 2007.

14. Song G, Quyang G and Bao S: The activation of Akt/PKB signaling pathway and cell survival. J Cell Mol Med 9: 59-71, 2005.

15. Neels JG and Olefsky JM: Cell signaling. A new way to burn fat. Science 312: 1756-1758, 2006.

16. Tian R: Another role for celebrity: Akt and insulin resistance. Circ Res 96: 139-140, 2005

17. Lawlor MA and Alessi DR: PKB/Akt: a key mediator of cell proliferation, survival and insulin responses? J Cell Sci 114: 2903-2910, 2001.

18. Yang J, Cron P, Thompson V, Good VM, Hess D, Hemmings BA and Barford D: Molecular mechanism for the regulation of protein kinase B/Akt by hydrophobic motif phosphorylation. Mol Cell 9: 1227-1240, 2002.

19. Yang J, Cron P, Good VM, Thompson V, Hemmings BA and Barford D: Crystal structure of an activated Akt/protein kinase B ternary complex with GSK3-peptide and AMP-PNP. Nat Struct Biol 9: 940-944, 2002.

20. Huang X, Begley M, Morgenstern KA, Gu Y, Rose P, Zhao H and Zhu X: Crystal structure of an inactive Akt2 kinase domain. Structure 11: 21-30,2003.

21. Kumar CC and Madison V: Akt crystal structure and Akt-specific inhibitors. Oncogene 24: 7493-7501, 2005.

22. Fayard E, Tintignac LA, Baudry A and Hemmings BA: Protein kinase B/Akt at a glance. J Cell Sci 118: 5675-5678, 2005.

23. Brazil DP, Yang ZZ and Hemmings BA: Advances in protein kinase B signaling: AKTion on multiple fronts. Trends Biochem Sci 29: 233-242, 2004.

24. Brazil DP, Park J and Hemmings BA: PKB binding proteins: getting in on the Akt. Cell 111: 293-303, 2002.

25. Huang BX and Kim HY: Interdomain conformational changes in Akt activation revealed by chemical cross-linking and tandem mass spectrometry. Mol Cell Proteomics 5: 1045-1053, 2006. 
26. Sugita H, Kaneki M, Sugita M, Yasukawa T, Yasuhara S and Martyn JA: Burn injury impairs insulin-stimulated Akt/PKB activation in skeletal muscle. Am J Physiol Endocrinol Metab 288: E585-E591, 2004.

27. Carvalho-Filho MA, Ueno M, Hirabara SM, Seabra AB Carvalheira JB, de Oliveira MG, Velloso LA, Curi R and Saad MJ: S-nitrosation of the insulin receptor, insulin receptor substrate 1, and protein kinase B/Akt: novel mechanism of insulin resistance. Diabetes 54: 959-967, 2005.

28. Yasukawa T, Tokunaga E, Ota H, Sugita H, Martyn JA and Kaneki M: S-Nitrosylation-dependent inactivation of Akt/protein kinase B in insulin resistance. J Biol Chem 280: 7511-7518, 2005.

29. Carter EA, Derojas-Walker T, Tamir S, Tannenbaum SR, Yu YM and Tompkins RG: Nitric oxide production is intensely and persistently increased in tissue by thermal injury. Biochem J 304: 201-204, 1994.

30. Auguin D, Barthe P, Auge-Senegas MT, Stern MH, Noguchi M and Roumestand C: Solution structure and backbone dynamics of the Pleckstrin homology domain of the human protein kinase $\mathrm{B}$ (PKB/Akt). Interaction with inositol phosphates. J Biomol NMR 28: 137-155, 2004

31. Murata H, Ihara Y, Nakamura H, Yodoi J, Sumikawa K and Kondo T: Glotaredoxin exerts an antiapoptotic effect by regulating the redox state of Akt. J Biol Chem 278: 50226-50233, 2003.

32. Lu XM, Lu MY, Fischman AJ and Tompkins RG: A new approach for sequencing human IRS1 phosphotyrosine-containing peptides using CapLC-Q-TOF(micro). J Mass Spectrom 40: 599-607, 2005.

33. Lu XM, Lu M, Tompkins RG and Fischman AJ: Site-specific detection of S-nitrosylated PKBa/Akt1 from rat soleus muscle using CapLC-Q-TOF(micro) mass spectrometry. J Mass Spectrom 40: $1140-1148,2005$

34. Jaffrey SR, Erdjument-Bromage H, Ferris CD, Tempst $P$ and Snyder SH: Protein S-nitrosylation: a physiological signal for neuronal nitric oxide. Nat Cell Biol 3: 193-197, 2001.

35. Jaffrey SR and Snyder SH: The biotin switch method for detection of S-nitrosylated proteins. Science STKE 86: 1-9, 2001.

36. Greco TM, Hodara R, Parastatidis I, Heijnen HFG, Dennehy MK, Liebler DC and Ischiropoulos H: Identification of S-nitrosylation motifs by site-specific mapping of the S-nitrosocysteine proteome in human vascular smooth muscle cells. Proc Natl Acad Sci USA 103: 7420-7425, 2006.
37. Hao G, Derakhshan B, Shi L, Campagne F and Gross SS: SNOSID, a proteomic method for identification of cysteine S-nitrosylation sites in complex protein mixtures. Proc Natl Acad Sci USA 103: 1012-1017, 2006

38. Kuncewicz T, Sheta EA, Goldknopf IL and Kone BC: Proteomic analysis of S-nitrosylated proteins in mesangial cell. Mol Cell Proteomics 2: 156-163, 2003.

39. Martinez-Ruiz A and Lamas S: Detection and proteomic identification of S-nitrosylated proteins in endothelial cells. Arch Biochem Biophys 423: 192-199, 2004.

40. Gan HT and Chen JDZ: Roles of nitric oxide and prostaglandins in pathogenesis of delayed colonic transit after burn injury in rats. Am J Physiol Regul Integr Comp Physiol 288: R1316-R1324, 2005.

41. Torres SH, De Sanctis JB, de L Briceno M, Hernandez N and Finol HJ: Inflammation and nitric oxide production in skeletal muscle of type 2 diabetic patients. J Endocrinol 181: 419-427, 2004.

42. Benhar M, Forrester MT and Stamler JS: Nitrosative stress in the ER: a new role for S-nitrosylation in neurodegenerative diseases. ACS Chem Biol 1: 355-358, 2006.

43. Tannenbaum SR and White FM: Regulation and specificity of S-nitrosylation and denitrosylation. ACS Chem Biol 1: 615-618, 2006.

44. Hogg N: The biochemistry and physiology of S-nitrosothiols. Ann Rev Pharmacol Toxicol 42: 585-600, 2002.

45. Arnelle DR and Stamler JS: $\mathrm{NO}^{+}, \mathrm{NO}$, and $\mathrm{NO}^{-}$donation by S-nitrosothiols: implications for regulation of physiological functions by S-nitrosylation and acceleration of disulfide formation. Arch Biochem Biophys 318: 279-285, 1995.

46. Carvalho-Filho MA, Ueno M, Carvalheira JB, Velloso LA and Saad MJ: Targeted disruption of iNOS prevents LPS-induced S-nitrosation of IRbeta/IRS-1 and Akt and insulin resistance in muscle of mice. Am J Physiol Endocrinol Metab 291: E476-E482, 2006.

47. Wu WI, Voegtli WC, Sturgis HL, Dizon FP, Vigers GP and Brandhuber BJ: Crystal structure of human AKT1 with an allosteric inhibitor reveals a new mode of kinase inhibition. PLos One 5: e12913, 2010.

48. Kloet DE and Burgering BM: The PKB/FOXO switch in aging and cancer. Biochim Biophys Acta 1813: 1926-1937, 2011. 